RESEARCH ARTICLE

\title{
Temporal Variability in the Precipitation Concentration at Salem District of Tamil Nadu
}

\author{
Raviraj $\mathrm{A}^{1}$ Thiyagarajan $\mathrm{G}^{{ }^{*}}$ Ramachandran $\mathrm{J}^{2}$ and Panneerselvam $\mathrm{S}^{1}$ \\ *1Water Technology Centre, Tamil Nadu Agricultural University, Coimbatore-641 003 \\ ${ }^{2}$ Department of Agricultural Engineering, Agricultural College and Research Institute, Madurai -625 104
}

\begin{abstract}
The temporal behavior of precipitation is more important in crop planning and prediction of extreme events. Salem District is one of the land-protected districts in Tamil Nadu. The main objectives of this study is to describe the temporal patterns of rainfall amount and concentration of Salem District. The rainfall data for various locations and at different course of time were collected from Indian Meteorological Department (IMD) and analyzed to study the variability of rainfall in Salem district. It receives rainfall under influence of both southwest and northeast monsoons. It was observed that the maximum rainfall in the district was recorded in $2005(1375 \mathrm{~mm})$ and the minimum rainfall was recorded in 1980 (51 $\mathrm{mm})$. It was also observed

Received : $10^{\text {th }}$ June, 2020

Revised : $06^{\text {th }}$ July, 2020

Revised : $19^{\text {th }}$ August, 2020

Accepted : $27^{\text {th }}$ August, 2020 from the annual rainfall plot that the rainfall in the district is uneven. The overall average annual rainfall of the district over the years is around $81 \mathrm{~mm}$. The maximum number of rainy days was recorded in 2010 (91 days). The station wise average rainfall analysis showed that that the Yercadu station has recorded the highest average annual rainfall of $1223.16 \mathrm{~mm}$ compared to the other stations. The major contribution of rainfall to the district is from the South-west monsoon, which is about $42 \%$, followed by the northeast, which is $38 \%$. On an average, the north- east monsoon contributed a maximum of $306 \mathrm{~mm}$ to the total rainfall in the district and the minimum rainfall was recorded during the winter season. Between 1977 and 2012, the maximum rainfall was observed in $2005(1375 . \mathrm{mm})$ which has its highest contribution from the northeast monsoon. In addition, the highest record of northeast monsoon had been recorded in 2005 (712 mm). Around 20 years, the rainfall is lesser compared to the average annual rainfall $(812 \mathrm{~mm})$. Hence, the district has not experienced any major distress with respect to rainfall as majority of years fall under normal category. This temporal variability analysis of rainfall in the district helps in crop planning and proposing water conservation activities.
\end{abstract}

Keywords: Crop planning; Precipitation; Rainfall distribution; Temporal variability.

\section{INTRODUCTION}

Rainfall is a prime source of water for human activities. The changing precipitation pattern, and its impact on surface water resources, is an important climatic problem facing society today. Understanding rainfall characteristics plays a vital role in sustainable watershed development and management. Rainfall characteristics also help in setting up irrigation networks, water storage reservoirs and identifying cropping pattern. Knowledge on rainfall temporal structure is an important factor in all planning and monitoring studies.

Research into historical changes in the climatic system using instrumental records were recognized as one of the necessities of climate change research (Houghton et al., 1990, Manikandan et al., 2011). Peleg et al., (2017) defined Spatial variability as "the variability derived from having multiple spatially distributed rainfall fields for a given point in time". Several studies were done regarding spatial and temporal variation of rainfall throughout India and around the globe. Subbaramayya and Naidu (1992) and Ghosh et al., (2009) analyzed the spatiotemporal variations of Indian monsoon rainfall. Jagannadhasarma (2005) has analyzed the rainfall pattern of the coastal zone of KrishanaGodavary River Basin Andhra Pradesh, India and analyzed the annual and monsoon rainfall and spatial and frequency distribution of rainfall intensity. Vennila 
(2007) has analysed rainfall variation analysis of Vattamalaikarai sub basin, Tamil Nadu, India.

Saikia et al., (2007) attempted to evaluate the pattern of changing temperature and rainfall in Umiam region of Meghalaya assuming that more or less the completely northeastern hill region has the same pattern. Sheoran et al., (2008) examined the long-term averages of annual, seasonal, monthly and weekly rainfall and its temporal variability of rainfall recorded at RRSKA, Ballowal Saunkhri, District Nawanshahr, and Punjab.

With this background, the main objectives of this paper is to describe the temporal variation of rainfall characteristics including annual and monthly rainfall concentration of Salem District located in Tamil Nadu.

\section{MATERIAL AND METHODS}

\section{About the Study Area}

The Salem district is located in $11.6643^{\circ} \mathrm{N}$, $78.1460^{\circ} \mathrm{E}$ and receives the rainfall under the influence of both southwest and northeast monsoons. The southwest monsoon chiefly contributes to the rainfall in the district. A perusal of the data showed that the normal annual rainfall over the district varies from about $500 \mathrm{~mm}$ to $1200 \mathrm{~mm}$. The district enjoys a tropical climate (Figure 1). The important food crops are paddy, cholam, cumbu, ragi, red gram, green gram, black gram, horse gram, turmeric, sugarcane, mango, banana, tapioca, groundnut and gingelly. The other important crops are cotton, castor seed and coffee.

\section{Data Collected}

The rainfall data for various locations of Salem district and at different course of time were collected from Indian Meteorological Department (IMD) and analyzed to study the variability in rainfall. Rainfall data from fifteen stations during the period between 1977 to 2011 were utilized. The major stations taken into consideration are Anaimudi, Athur, Gangavalli, Kolathur, Kullampatti, Mettur, Nangavalli, Omalur, Pillukurichi, Salem, Sankagiri, Thammampatti, Valapadi, Veeraganur and Yercadu.

\section{Rainfall mean characteristics}

Annual rainfall $(\mathrm{R})$ for each station was calculated. The temporal annual average rainfall and station wise annual average rainfall are calculated for Salem district. According to India Meteorological Department (IMD), a rainy day has been defined as a day with rainfall of $2.5 \mathrm{~mm}$ or more rainfall. IMD further defines that rainfall for a station is called heavy if it is greater than $650 \mathrm{~mm}$ and very heavy if it is greater than $1300 \mathrm{~mm}$. The number of rainy days was calculated by accounting days having rainfall greater than $2.5 \mathrm{~mm}$. It helps in depicting the facts about rainfall localization. The station wise temporal variation of rainfall was also analyzed. The decadal changes of rainfall was estimated spatially for Salem district.

\section{RESULTS AND DISCUSSION}

\section{Rainfall and Rainy days}

The average annual rainfall of the district from 1977 to 2012 was done and the overall average annual rainfall of the district over the years is around $812 \mathrm{~mm}$.

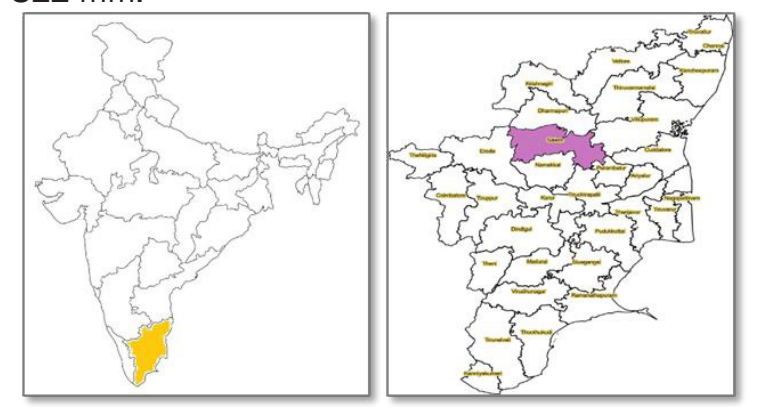

Figure 1. Location map of Salem district

From Figure 2, it was observed that the maximum rainfall in the district was recorded in 2005 (1375 $\mathrm{mm}$ ) and the minimum rainfall was recorded in 1980 (51 mm).

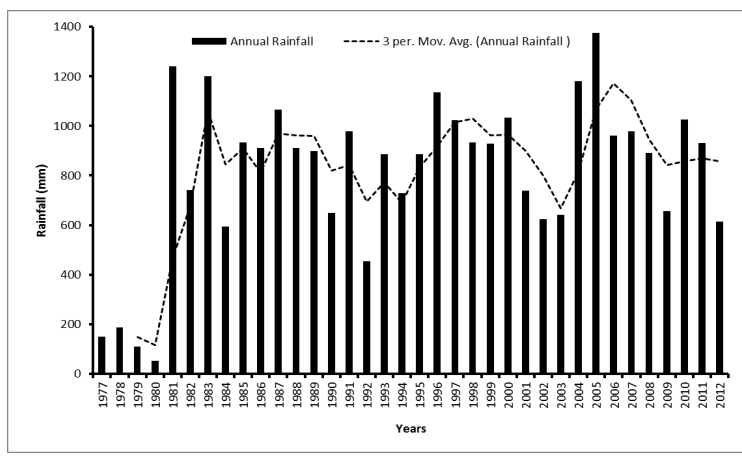

Figure 2. Annual Rainfall with moving average of the District

It was observed from the plot that the rainfall in the district is distributed unevenly. The maximum number of rainy days was recorded in 2010 (91 days) (Figure 3).

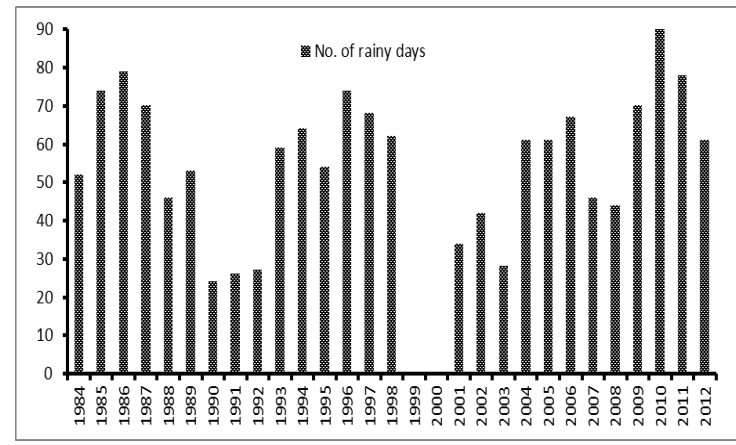

Figure 3. Rainy Days in Salem District 
From Figure 4, it was found that the Yercadu station has recorded the highest average annual rainfall of $1223 \mathrm{~mm}$ compared to the other stations.

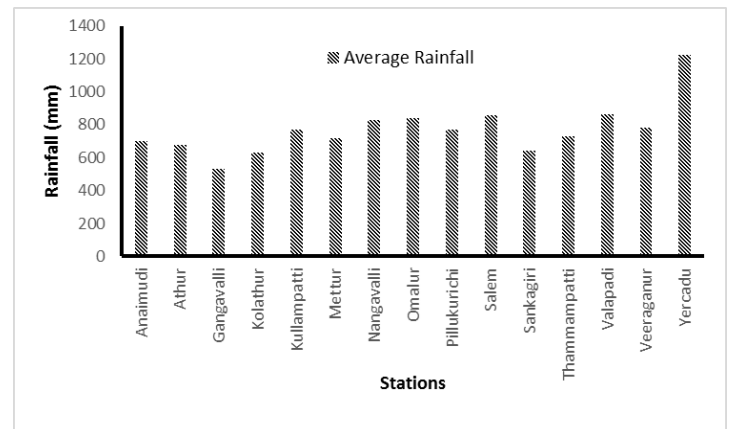

Figure 4. Station Wise Average Rainfall

It is minimum in Gangavahlli $(533 \mathrm{~mm}$ ) in the central eastern part of the district. It gradually increases towards south, west, and north and attains a maximum in Yercadu $(1223 \mathrm{~mm})$ in the northern part.

\section{Seasonal distribution of rainfall}

The seasonal rainfall distribution is an important parameter to be assessed for the agricultural community to decide the cropping pattern and their irrigation sources. The contribution of rainfall in winter, summer, southwest monsoon and the Northeast monsoon was represented in the chart (Figure 5).

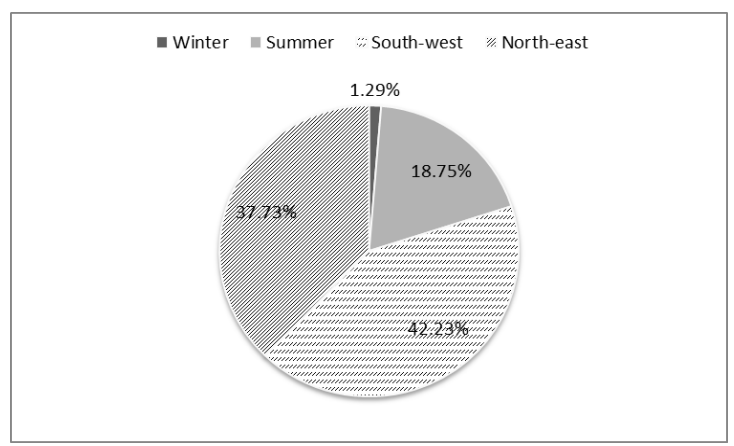

\section{Figure 5. Seasonal Distribution of Rainfall}

The major contribution of rainfall to the district is from the Southwest monsoon, which is about $42 \%$ followed by the northeast, which is $38 \%$ (Figure 5). Sheoran et al., (2008) also concluded that there is scope for rainwater harvesting from July to September, which can be utilized as crop saving irrigation as well as pre-sowing irrigation for succeeding rabi crops which are generally sown on residual soil moisture at Nawanshahr District, Punjab.Thirumarran et al., (2019) observed that the trend of rainfall is increasing over Tamil Nadu and Pondicherry region for the Northeast monsoon rainfall.
On an average, the northeast monsoon contributed a maximum of $306.43 \mathrm{~mm}$ to the total rainfall in the district and the minimum rainfall was recorded during the winter season. Between 1977 and 2012 , the maximum rainfall was observed in 2005 (1375 mm) which has its highest contribution from the northeast monsoon. Also, the highest record of north east monsoon have been recorded in 2005 (712 mm) (Figure 6).

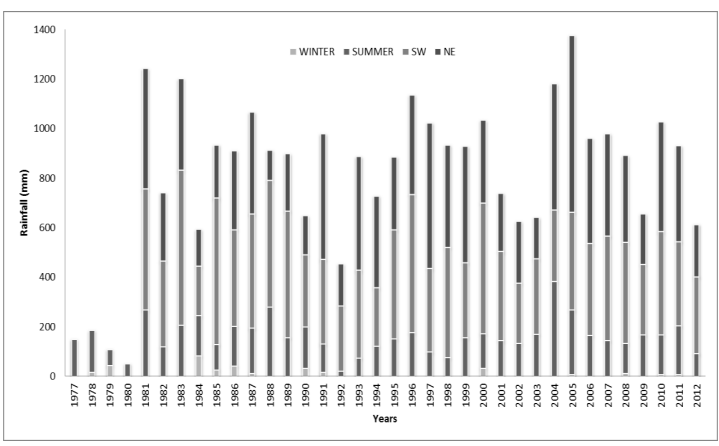

Figure 6. Temporal variation of seasonal average rainfall from 1977-2012

The rainfall distribution during the north east monsoon as depicted in Figure 6 which shows the highest record of rainfall is obtained in the year 2005. This result helps in location specific crop planning and will be a useful in crop water requirement studies.

\section{Annual normal rainfall}

The annual normal rainfall indicates the percentage deviation of any year's rainfall from the average rainfall.

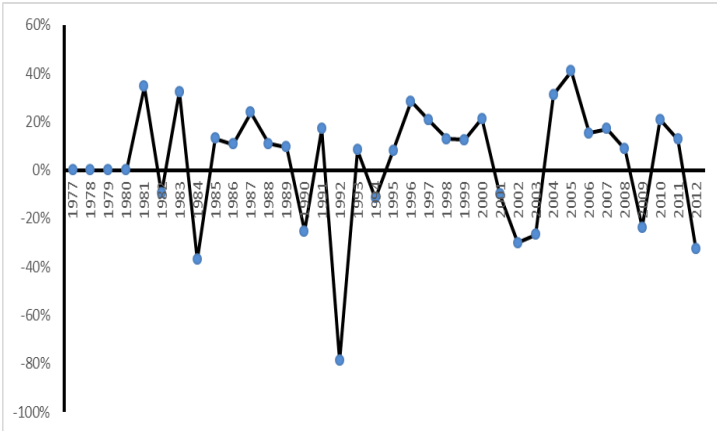

Figure 7. Percent annual normal rainfall of the district

The deviations are both positive and negative indicating the irregularities in the rainfall over the years. The mean annual rainfall of the district was shown in Figure 2 along with the moving average curve. The percent annual rainfall is shown in the Figure 7. Around 20 years, the rainfall is lesser compared to the average annual rainfall (812 $\mathrm{mm}$ ). It was found that the district has not experienced any major stress with respect to rainfall as majority 
of years fall under normal category.

\section{CONCLUSION}

The overall average annual rainfall of the district over the years was around $812 \mathrm{~mm}$. The maximum number of rainy days was recorded in 2010 (91 days). The station wise average rainfall analysis showed that the Yercadu station has recorded the highest average annual rainfall of $1223 \mathrm{~mm}$ compared to other stations. The major contribution of rainfall to the district was from the Southwest monsoon, which is about $42 \%$ followed by the northeast, which is $38 \%$. On an average, the northeast monsoon contributed a maximum of $306 \mathrm{~mm}$ to the total rainfall in the district and the minimum rainfall was recorded during the winter season. Around 20 years, the rainfall is lesser compared to the average annual rainfall $(812 \mathrm{~mm})$. The district has not experienced any major distress with respect to rainfall as majority of years fall under normal category. This temporal variability analysis of rainfall in the district helps in crop planning and proposing water conservation activities. Further, spatial distribution rainfall mapping will serve as a tool in identifying the low and high rainfall regions within the district, which will enhance the crop planning.

\section{REFERENCES}

Ghosh, S., Luniya, V. and A. Gupta. 2009. Trend analysis of Indian summer monsoon rainfall at different spatial scales. Atmos. Sci. Lett. 10: 285-290.
Houghton, J.T., Jenkins, G.J., and Ephraums JJ (eds). 1990. Climate Change: The IPCC Scientific Assessment. Cambridge University Press: Cambridge.

Jagannadhasarma, V.V. 2005. Rainfall pattern in the coastal zone of Krishna Godavary basin Andhra Pradesh India. Journal of Applied Hydrology. 18(1\&2): 111

Manikandan, M., Thiyagarajan, G and Vijayakumar, G. 2011. Probability analysis for estimating annual one day maximum rainfall in Tamil Nadu Agricultural University. Madras Agric. J.,98 (1-3): 69-73.

Peleg, N., Blumensaat, F., Molnar, P., Fatichi, S., and Burlando, P. 2017 Partitioning the impacts of spatial and climatological rainfall variability in urban drainage modeling, Hydrol. Earth Syst. Sci., 21: 1559-1572.

Saikia, S.U., K.K. Satapathy, B. Goswami, R. K. Singh and B.K. Rao. 2007. Trend of rainfall and temperature change at umiam, Meghalaya. Journal of Agrometeorology. 9(2): 203-208

Sheoran, P., Singh, S. P and Sardana, V. 2008. Rainfall analysis and crop planning in lower Shiwalik foothills of Punjab. Journal of Agrometeorology 10(2): 193-197.

Subbaramayya I., Naidu C.V. 1992. Spatial variations and trends in the Indian monsoon rainfall. Int. J. Climatol. 12: 597-609.

Thirumarran, M \& Padi, Tirupathi Rao \& Pt, Sakkeel. 2019. Annual Rainfall Pattern and Analysis for Eastern and Western Parts of Tamil Nadu.

Vennila, G. 2007. Rainfall variation analysis of Vattamalaikarai sub basin, Tamil Nadu. Journal of Applied Hydrology. 3: 5059 